\title{
PROMOTION IN ACADEMIC PROFESSION IN INDIA: UPWARD MOBILITY OF TEACHERS IN HIGHER EDUCATION
}

\author{
Jandhyala B. G. Tilak* and A. Mathew \\ National University of Educational Planning and Administration, \\ New Delhi 100016, India \\ *Corresponding author: jtilak@nuepa.org
}

Published date: 20 January 2017

To cite this article: Tilak J. B. G., \& Mathew, A. (2016). Promotion in academic profession in India: Upward mobility of teachers in higher education. Asia Pacific Journal of Educators and Education, 31, 85-114. http://dx.doi.org/10.21315/ apjee2016.31.6

To link to this article: http://dx.doi.org/10.21315/apjee2016.31.6

\begin{abstract}
The paper presents a commentary on the status of academic profession in India, focusing on the system of promotion of teachers in higher education and the current economic status. It critically reviews the present system, introduced in 2010 and revised in 2013, which is regarded as a major attempt to raise standards in higher education, providing significant pay hike, opportunities for fair upward mobility and at the same time making teachers in universities and colleges accountable. Reviewing the scheme, the paper also examines how it is perceived by the teaching community.
\end{abstract}

Keywords: teachers, higher education, India, career advancement scheme, pay scales, university grants commission

\section{INTRODUCTION}

The importance of higher education in national development has been well recognised during the post-independence period in India. The critical role of the academic profession in providing high quality higher education and research, necessary for national development, is also well noted, when it was stated, "the academic profession is the mother of all professions in the society" (University Grant Commision [UGC], 1997). National Commission on Teachers [NCT] (1985) further noted, "It is important to have adequate and suitable opportunities for professional and career development." As a corollary, various governmental committees and commissions paid serious attention to the issues relating to 
academic profession in higher education, including qualifications for teachers, teacher recruitment, promotion and upward mobility in their academic career, and faculty development in general. Almost at regular intervals, committees are enjoined by the Government of India to examine the pay and promotional structure as well as the service conditions of the teachers so as to ensure attracting and retaining the best talents in teaching profession in the country, and they have made important recommendations on the issues of revision of salary scales as well as promotional avenues for the teachers in higher education which formed the basis for modifications and improvement in the system. However, academic profession in India is carrying a mixed bag of problems. This paper presents a critical review of a few critical issues relating to academic profession in Indian higher education system, essentially focusing on teachers, their recruitment and their upward mobility.

\section{HIGHER EDUCATION IN INDIA}

Higher education in India has expanded very fast during the post independence period - from an extremely small base consisting of 32 universities, 700 colleges $^{1}$ and 0.4 million students at the inception of planning in the country in 1950-1951, to more than 750 universities, 39,700 colleges and about 24 million students in 2013-2014. In terms of the current size, the higher education system in India is the second largest one in the world, next only to China. The US system now comes only after India. These numbers make some to observe that the higher education system is about to enter the phase of 'massification' or mass higher education, though the enrolment ratio is only about $20 \%$, and it is generally felt that only if the ratio crosses $40 \%$, the country can be regarded as moving into the phase of massification.

The phenomenal expansion of higher education has contributed a lot to many spheres of socio economic development of the country. First, with massive expansion of higher education, the country could achieve self reliance in manpower needs, in the sense that no sector of the society - whether it is manufacturing sector or service sector, including planning, administration, defense, science and technology, etc., or high technology intensive sector, critically depends upon foreign or expatriate manpower. The country can even boast of exporting manpower and making substantial earnings in terms of foreign exchange. For example, it is proudly stated that the Silicon Valley in the USA critically depends upon information and technology (IT) manpower produced by the higher education system in India. Brain drain has become no more a matter of concern. Secondly, with such an expansion, the higher education system itself could get democratised: achieving a fair degree of gender parity - around $40 \%$ cent of the enrolments in higher education being women; and making good 
progress in social equity - about one-third of students coming from socially backward strata of the society. Third, in terms of quality and excellence, a few institutions of higher education, such as the Indian Institutes of Technology, Indian Institute of Science, and even some central/state universities, and some centres of advanced studies could stand as exceptional ones in the country. Fourth, higher education played a significant part in socio-economic development of the country, including economic growth, reduction in poverty, improvement in inequalities, and human development. Contribution of higher education to strengthening democracy and political stability has also been quite important.

However, at the same time, the system suffers from severe inadequacies: first, though in terms of absolute numbers, the higher education system is the second largest one in the world, with about $20 \%$ enrolment ratio, India still ranks poorly even among the developing countries. Higher education with such a low enrolment ratio is argued to be not at all adequate to meet the growing socioeconomic needs of the country, particularly to transform the country into a knowledge society, to sustain high rates of economic growth, and to come out of the group of 'developing' countries. It is generally argued that a gross enrolment ratio of $30 \%-40 \%$ is the threshold level for a country to aim at becoming a fast growing economy. Secondly, in terms of quality of higher education, it is widely felt that though there are a few institutions of high quality, they are only pockets of excellence and hardly any Indian institution figures among the top 200 in global rankings of universities. The system as a whole is characterised by mediocre quality and moreover the standards are rapidly falling. Very small proportions of graduates are reported to be employable. Third, while there has been somewhat impressive improvement in gender equity and also in access of the socially backward sections to higher education, regional - rural and urban, inter-state, and intra-state inequalities are still very high in higher education. Inequalities between the rich and the poor in participation rates in higher education are found to be the highest and they seem to be increasing.

Thus the system of higher education is characterised by a few major strengths and a few equally important shortcomings. Recognising the need for expansion and overall improvement in higher education, the Government of India had set a target of $30 \%$ gross enrolment ratio by 2030 , and launched massive expansion programme, which along with high growth of private institutions of higher education is expected to enable rapid growth in enrolments in higher education.

\section{ACADEMIC PROFESSION}

Presently nearly a little above one million teachers are employed in higher education institutions in the country. In 1950-1951, there were barely 24 
thousand teachers. The increase in the number of teachers has been phenomenal, going up by 43 times during the 64 -year period. However, the rate of growth in the number of teaches has not kept pace with increase in number of institutions and enrolments, as one can note from Table 1. High growth in the number of teachers (16-20\% per annum) took place only in the first two decades, followed by least rates of growth (below 5\%) in the following three decades.

Table 1. Growth in Teachers in Higher Education in India

\begin{tabular}{cc}
\hline Year & Number of teachers (in thousands) \\
\hline $1950-1951$ & 24 \\
$1960-1961$ & 62 \\
$1970-1971$ & 190 \\
$1980-1981$ & 244 \\
$1990-1991$ & 271 \\
$2000-2001$ & 350 \\
$2005-2006$ & 488 \\
$2010-2011$ & 817 \\
$2013-2014$ & 1,049 \\
\hline
\end{tabular}

Source: Ministry of Human Resource Development (various years); UGC (various years)

Table 2. Average Annual Growth in Higher Education in India (\%)

\begin{tabular}{ccccc}
\hline Year & Enrolment & Teachers & Colleges & Universities \\
\hline $1950-1951$ to $1960-1961$ & 22.01 & 15.83 & 21.47 & 6.07 \\
$1960-1961$ to $1970-1971$ & 25.12 & 20.65 & 8.02 & 10.67 \\
$1970-1971$ to $1980-1981$ & 4.07 & 2.84 & 3.97 & 3.23 \\
$1980-1981$ to $1990-1991$ & 5.99 & 1.11 & 4.48 & 4.96 \\
$1990-1991$ to $2000-2001$ & 10.32 & 4.58 & 5.32 & 3.80 \\
2000-2001 to 2010-2011 & 12.26 & 13.34 & 21.69 & 14.45 \\
$2010-2011$ to 2013-2014 & 9.09 & 9.47 & 7.76 & 5.04 \\
$1950-1951$ to 2013-2014 & 13.09 & 9.71 & 10.68 & 7.09 \\
\hline
\end{tabular}

Source: Based on Ministry of Human Resource Development (various years); and UGC (various years)

As a result, a severe degree of shortage of teachers is felt in almost all institutions of higher education - universities - central and state, colleges and specialised institutions like the Indian Institutes of Technology. The shortage of teachers has also resulted in increase in pupil-teacher ratios, as shown in Table 3. Though at national level, it is 23 , in a good number of colleges it ranges between 30 and 36 
(Qamar, 2008). These ratios in India are found to be very high, compared to many other universities in other countries.

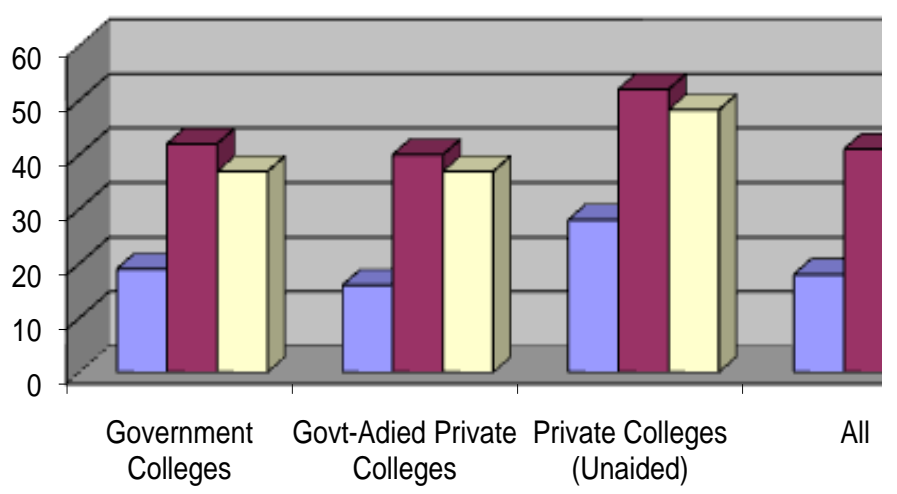

Figure 1. Percentage of vacant teaching positions in colleges, 2007-2008 (Source: Chadh, Bhushan, \& Murlidhar, 2008)

Table 3. Pupil-teacher ratio in higher education in India (Source: UGC Annual Reports)

\begin{tabular}{lcc}
\hline & $1995-1996$ & $2013-2014$ \\
\hline Universities & 15.0 & 17.7 \\
Colleges & 22.4 & 23.7 \\
\hline Total & 20.7 & 22.7 \\
\hline
\end{tabular}

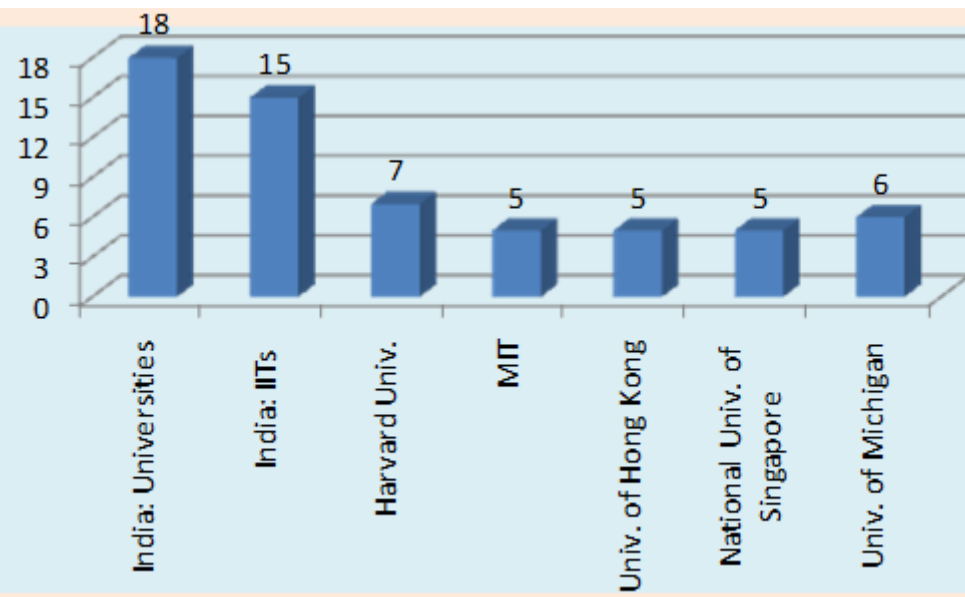

Figure 2. Pupil-teacher ratio in selected universities (around 2013) 
Further, a few important characteristic features of the teaching manpower employed in higher education institutions may be noted. The hierarchy of teachers in higher education starts, as per the present system, with Tutors/Demonstrators and goes up to Professors with High Academic Grade, with six categories. Within Lectures/Assistant Professors, there are three grades/stages; Readers/Associate Professors is the middle category and Professors the highest level in the teacher hierarchy in higher education. Thus, the presently prevailing hierarchy of teachers in higher education in India is as follows:

1. Tutors/Demonstrators (Others)

2. Lecturers/assistant Professors

(a) Lecturers (Stage 1)

(b) Senior Lecturers (Stage 2)

(c) Senior Grade Lecturers (Stage 3)

3. Readers/Associate Professors (Stage 4)

4. Professors (mostly in universities only)

(a) Professors (Stage 5)

(b) High Academic Grade Professors (Stage 6)

Though there are six levels of academic positions, substantial ones are only three in most higher education institutions, as standardised since 2006: Lecturer/Assistant Professor, Reader/Associate Professor and Professor. Tutors/Demonstrators (Others) are not considered as core academic staff. They are regarded as supporting or para academic staff.

As indicated in Table 4, as per the latest statistics, nearly $62 \%$ of the teachers are assistant professors (including Lecturers in Senior Scale); $9 \%$ are full professors; and the remaining $26 \%$ are associate professors. An overwhelming majority of teachers in higher education are in the colleges - undergraduate and postgraduate colleges, accounting for $83 \%$, while $17 \%$ of them are in the universities. Within the universities, $17 \%$ are full professors, $25 \%$ are associate professors, and 53\% work as lecturers (including Senior Grade Lectures). Most of the colleges offer under graduate programmes, while universities mostly offer post graduate and research programmes. There are no provisions for transfer of teachers from colleges to universities; transfers are also not allowed among universities, and between several states in case of colleges. They are at best transferable from one government college to another government college within a state. 
Table 4. Teachers in Higher Education in India, 2013-2014 (Source: UGC annual report 2013-2014)

\begin{tabular}{lcccccc}
\hline & \multicolumn{2}{c}{ Universities $^{*}$} & \multicolumn{2}{c}{ Colleges $^{* *}$} & \multicolumn{2}{c}{ Total } \\
\cline { 2 - 7 } & No. & $\%$ & No. & $\%$ & No. & $\%$ \\
\hline Professors & 30272 & 16.7 & 65859 & 7.6 & 96131 & 9.2 \\
Readers/Associate Professors & 46102 & 25.4 & 227702 & 26.3 & 273804 & 26.1 \\
Senior Lecturers/ Assistant & 17238 & 9.5 & 92850 & 10.7 & 110088 & 10.5 \\
Professors & 79372 & 43.8 & 456301 & 52.6 & 535673 & 51.1 \\
Lecturers/Assistant Professors & 8434 & 4.7 & 24795 & 2.9 & 33229 & 3.2 \\
Tutors/Demonstrators & 181418 & 100.0 & 867507 & 100.0 & 1048925 & 100.0 \\
\hline Total & & & & & \\
\hline Notes: * includes university colleges; ** affiliated colleges & & & & &
\end{tabular}

Others, 3.2

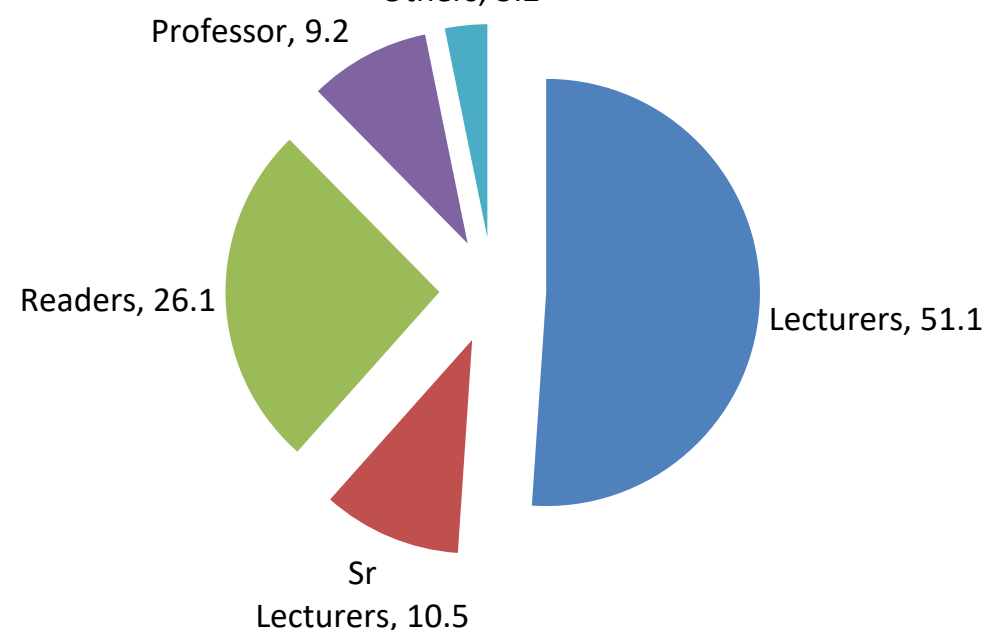

Figure 3. Distribution of Teachers in Higher Education in India, by level, 2012-2013 (\%) (Source: Based on UGC Annual Report 2013-2014)

An important problem with the academic profession in India is that there had been a de facto official ban on recruitment of university teachers (and nonteachers as well) in many universities and colleges. This follows the introduction of economic reform policies in the early 1990s that required downsizing of all public sector units including higher education institutions. The block grants provided by the state governments to the universities have also remained virtually frozen for quite some time. Thus the depleting size of the faculty and the frozen state grants have caused a serious damage on the morale and motivation of the teachers, the physical ambience of the universities and the overall academic 
environment of the universities, as many departments and postgraduate centres of the universities are sub-critical in the size of the teaching staff, and are also subcritical in their performance, offering few high quality teaching and research programmes. Universities were to resort to various methods, many of which are not necessarily desirable, to tide over the twin problems. Shortage of full time faculty forced them to recruit temporary teachers with varied designations like part-time teachers, guest teachers, contract teachers, and teaching assistants, at very low consolidated salaries, sometimes at a salary level of one-fifth of regular teachers. Recruitment of temporary teachers, even under-qualified, on contract with inferior service conditions is a widespread phenomenon. All this is akin to the phenomenon of para-teachers in the school system. Number of such teachers forms $15-60 \%$ of the total staff strength in various universities in one of the states in south India, and on average one out of every five teachers in colleges belongs to such category (Qamar 2008, p. 202). Many of these teachers may not necessarily be fulfilling the qualifications necessary for a regular university faculty member. But they seem to be continuing for several years. Many of them are also recruited to teach "self financing courses", which are not funded by the government; the students pay for the total cost of studies in such courses. Over the years, such teachers are also recruited to teach normal regular courses of study. The long term effects of all this on the quality of teaching and research in higher education could be devastating, if a sizeable system of higher education were to survive with the help of part-time contract staff. The teaching profession is getting de-professionalised. Their role is changing from knowledge creators and transmitters of knowledge to knowledge managers, net-workers and fundraisers.

Policies of non-recruitment of teachers and the growth of market forces led to significant changes in research and teaching professions (Tilak, 2007). The emphasis slowly seems to be shifting from scholarly research to economically productive knowledge creation, from scholarly research to project based research, and from project based research to consultancy. In the area of teaching the shift is from promotion of scholarship to imparting of market relevant, saleable, and employable information and skills.

Teaching profession used to be highly respected with a high level of social status attached, though the salary structure in India was not encouraging. The National Committee on Teachers (1985) had gone into several aspects relating to the teaching profession in universities and colleges. But, while severe shortage of teachers and other problems like recruitment of temporary teachers, even underqualified ones on contract basis with inferior service conditions and vastly reduced pay package is a reality, the teachers' salary in universities and colleges have been revised with every Pay Commission's revision of salaries of government employees. 
Overall, there has been a steep decline in the status of teaching profession in the country, which used to be considered a unique profession of high respect (Jayaram, 2002). As Altbach (2002) paraphrases this, the decline of the Guru has become a phenomenon all over. Earlier the social status of the teachers used to be high, but their economic status was far from satisfactory. But in the recent years, the economic status improved, but there was a fall in the social status (see Basu, 2005). Traditionally teachers were regarded as God (Acharya Devobhava); in the later phase, teachers and students began to be treated as equal; and finally the roles got reversed, the students are treated as God, as in the market framework, customers is to be treated as God. Both students and teachers, who used to be in the forefront of civil, social and political movements in the country, seem to be slowly withdrawing into the background (Tilak, 2007).

\section{RECRUITMENT, QUALIFICATIONS AND PROMOTIONS OF TEACHERS}

Immediately after independence, the government of India recognised the need to set up proper mechanisms for recruitment of teachers in higher education and for their promotion.

The University Education Commission (1948-1949) bemoaned that the best talent in higher education did not return as teachers, but moved to provincial services and industry. It found a "great variety of salary scales" for teachers differing from government to government-aided and privately managed institutions, universities and colleges, general and technical institutions and teachers in professional and technical subjects to other subjects - meaning different scales of payment for the same type of work (Ministry of Education, 1950, p.73). It argued and advocated an improved and a uniform salary scales and better service conditions for teachers of universities and colleges. ${ }^{2}$ The Government of India (1986b, p. 141) further recognised that "the present system does not accord teachers a proper economic and social status, opportunities for professional and career development".

Recruitment to the teaching positions in higher education is made on the basis of merit through all India advertisement and Selection Committee as per University Statutes/Ordinances. According to the University Education (Radhakrishnan) Commission, "A Professor should be one who had taught the higher classes for a considerable number of years and established reputation for scholarship; ... he should have wide interest and a broad outlook to inspire and stimulate his colleagues and effectively contribute to the solution of academic problems of the university. ... the expected age when these qualifications are fulfilled is likely to be 48 years" (Ministry of Education, 1950). For the post of the Reader, the 
Commission said, "a research degree and published research work in recognised and well-established journals as the required qualifications". It felt that "a person of about 35 years should be able to fulfill these conditions". As for the Lecturer, the Commission felt the Necessary qualification, a first-class academic record; and the desirable qualification as "some teaching experience" and "should have started as a research scholar or a fellow and preferably should have completed his PhD." (Ministry of Education, 1950, pp. 74-75). It is important to note that even when the number of Doctorate degree holders in India at that time was extremely small (less than perhaps 100), the University Education Commission (1949) emphasised a research degree as essential for teachers in higher education especially in universities, as universities are conceived not only as teaching institutions but also equally, if not more, importantly research institutions.

Several years down the line did not witness any dilution in the prescription of the essential and necessary credentials needed for a teacher in higher education, though "in a number of Universities the standards appeared to have been diluted at several places because of unplanned growth, inadequate faculty and lack of infrastructural facilities" (Government of India, 1976). The Sen Committee (1976) was of the firm view that even at the entry level, i.e., for a Lecturer, "a Master's degree alone would not suffice for the selection of a Lecturer." It felt higher teaching/research/advanced study beyond the Master's degree, and an MPhil. or a $\mathrm{PhD}$, as essential qualifications for recruitment. This was obviously besides a good academic record especially at the Master's level with 55\% or more marks.

National Council on Teacher Education (NCTE) in collaboration with University Grants Commission (UGC) and the All-India Council on Technical Education (AICTE) are expected to ensure recruitment of properly qualified teachers in higher education institutions in India. UGC sets the guidelines for deciding workload of every teacher and correspondingly the number of teachers to be appointed in a given university/college.

The National Commission on Teachers for Higher Education (NCT, 1985) endorsed the minimum qualifications of teachers prescribed by the UGC in 1973, viz., a good academic record, with evidence of research capabilities, and a research degree and pedagogic skills. The Mehrotra Committee (UGC, 1986) noticed that the stipulation of $\mathrm{MPhiI} / \mathrm{PhD}$ as an essential qualification for Lecturers had neither been followed faithfully nor did it necessarily contribute to the raising of teaching and research standards. If at all, it had led to the dilution of research standards on account of the rush to get a research degree in the shortest possible time. It noted that the adoption of the $10+2$ pattern of schooling involved one additional year of education. Hence, it felt that a good 
MA/MSc/MCom, would be adequate as the minimum qualification for a Lecturer, and a research degree should be necessary only for career advancement. It suggested that additional increments be sanctioned to research degree holders at the time of selection as Lecturers to give due recognition to their research experience. This would attract bright young talent into the teaching profession. However, in view of the diversity of standards among universities, passing a national qualifying examination before recruitment should be made an essential precondition. Accordingly in order to ensure national standards of the teachers in higher education throughout the country, teachers in higher education institutions are recruited on the basis of a national eligibility test (NET) conducted by the UGC, and similar eligibility tests at the state level, namely the "state level eligibility test", conducted by state governments were introduced to ensure minimum uniform quality of teachers in higher education institutions. After all, teachers in higher education institutions do not receive any pre-service or even any substantial in-service training unlike school teachers in India. The NET as a minimum eligibility condition for teachers in the higher education institutions is relaxed in case of those teachers who possess research degrees (doctoral and predoctoral). In 2006, the NET has been abolished with a view to ease the problem of teacher shortage in many areas. But soon it was found that it is too important to abolish it and was reinstated.

Presently, a good academic record at Master's level from an Indian or accredited foreign university (with at least $55 \%$ marks or equivalent) ${ }^{3}$ is the basic condition, along with either a Doctorate Degree and/or pass in national eligibility test conducted specially for the post of lectureship/UGC fellowship, for entry into teaching profession, at the lowest level as Assistant Professor/Lecturer, while in addition to a good academic record at Masters' level, a Doctorate degree along with eight years teaching experience are essential prerequisites to be eligible for the post of Associate Professor. For the post of Professors one should have ten years of experience and a good publication record.

Table 5 gives the details on present minimum qualifications for various academic posts in universities and colleges. All these and other regulations that are discussed here are applicable to government and government-funded private higher education institutions, and are not applicable to other private institutions, though it would be desirable if the regulations are made applicable to all recognised institutions. 
Table 5. Qualifications for the Posts of Assistant Professors, Associate Professors and Professors in Universities and Colleges

\begin{tabular}{|c|c|}
\hline Post & Qualification \\
\hline \multirow[t]{2}{*}{ Professors } & $\begin{array}{l}\text { Minimum Qualification: } \\
\text { - } \quad \text { Good academic record with 55\% marks at Master level and qualifying } \\
\text { NET/SET/SLET } \\
\text { - Those with PhD and Masters level subjects not covered by NET now } \\
\text { are exempt from NET } \\
\text { - A relaxation of 5\% marks for SC/ST and differentially abled } \\
\text { - PhD Degree mandatory for appoint of Professors and promotion to } \\
\text { Professors and direct appointment of Associate Professors }\end{array}$ \\
\hline & $\begin{array}{l}\text { Desirable Qualification: (A) } \\
\text { - An eminent scholar with } \mathrm{PhD} \text { and published work, actively engaged in } \\
\text { research with minimum of } 10 \text { publications } \\
10 \text { years experience in teaching in university/colleges and/or } \\
\text { experience in research in university/national level institutions, } \\
\text { including guidance at doctoral level } \\
\text { - Contribution to educational innovations, design of new curriculum and } \\
\text { courses and technology } \\
\text { - Minimum API score } \\
\text { - or (B) An outstanding professional with established reputation in the } \\
\text { field }\end{array}$ \\
\hline Associate & - A good academic record with a PhD in relevant discipline \\
\hline Professor & $\begin{array}{l}\text { - Masters Degree with } 55 \% \text { marks or equivalent grade } \\
\text { Minimum } 8 \text { years experience in teaching and/or research in a position } \\
\text { equivalent to Assisstant Professor in a university/college/research } \\
\text { institution } \\
\text { - Contribution to educational innovation, design of new curricula and } \\
\text { courses } \\
\text { - Minimum API score as Performance Based Appraisal System (PBAS) }\end{array}$ \\
\hline $\begin{array}{l}\text { Assistant } \\
\text { Professor* }\end{array}$ & $\begin{array}{l}\text { - Good academic record at Master's level at an Indian or accredited } \\
\text { foreign university with at least } 55 \% \text { marks or an equivalent grade in } \\
\text { points scale } \\
\text { - NET/SET/SLET qualified } \\
\text { - Candidates with PhD will be exempted from NET/SET/SLET as } \\
\text { eligibility criterion } \\
\text { - NET not compulsory in respect of subjects at MA level where NET is } \\
\text { not conducted }\end{array}$ \\
\hline
\end{tabular}

*Assistant Professors in Art, Humanities, Sciences, Social Sciences, Commerce, Education, Languages, Law, Journalism and Mass Communication

Source: The Gazette of India, 18 September 2010, pp. 7850-7853. 


\section{Promotional Avenues and Upward Mobility of Teachers}

It has been long recognised that security of tenure and reasonable prospects of advancement in academic profession are essential to maintaining the health and tone of the service (Government of India, 1950). The Radhakrishnan Commission felt that the ratio between Professors and Readers on the one hand and Lecturers and Instructors on the other should be 1:2. A teacher entering the profession at the age of 22 or 23 as an Instructor or a Fellow, by the time he/she reached the maximum of the Lecturer grade, would have acquired sufficient experience and standing to be eligible for a Readership and could rise to a Professor's position at about 48 years of age in an open competition. "There should be opportunities for career advancement but only through selection in an open competition." According to the Sen Committee (Government of India, 1976), a Lecturer/Reader after completing six years of service could offer him/herself for higher position, by a duly constituted selection committee of the university on the basis of his qualification and work. The promotion in such a case should be regarded as a personal promotion, which implied that there should be no limit to the number of posts of Readers and Professors within the total sanctioned strength of the department. A suitable procedure for proper evaluation of the teacher would have to be evolved by the UGC. Teachers having similar qualifications, appointed to these posts by following the same criteria as those applicable to the university teachers, whether working in a university or a college, should have a similar scale of pay.

The NCT (1985) felt that "it is important to have adequate and suitable opportunities for professional and career development". But the National Commission did not favour promotion by seniority as a proxy for merit. Instead, it argued that promotion should be based on continuous record of the work of a teacher, in teaching, research, extension and administration. Career advancement should be linked to faculty development. Government of India (1986b) deplored the lack of promotional opportunities such as opportunities for professional and career development, initiative for innovation and creative work, proper orientation in concept, techniques and value system to fulfill their role and responsibilities.

\section{METHODS OF PROMOTION/UPWARD MOBILITY}

Two methods of promotion have been in vogue in the higher education system ever since the formulation of the National Policy on Education 1986 (Government of India, 1986a), viz., (i) Open competition, which had been the only method available for promotion for a long time, and (ii) merit promotion under Career Advancement Scheme (CAS) introduced after 1986. The general 
principles that guide promotion in both cases are non-discrimination, reservations for backward social groups of population (Scheduled Cates, Scheduled Tribes and Other Backward Classes), ${ }^{4}$ merit/performance of the candidate, transparency, and welfare of the teachers. Teachers are assessed and graded annually through performance based appraisal system (PBAS) based on their performance and are considered for promotion. Promotion is considered as a mechanism to promote morale and commitment to the profession and as an incentive for better performance.

\section{Promotion through Competition (Direct Recruitment/Open Competition)}

Whenever a vacancy for an academic post arises or a new position is created, the position is filled through open competition, where faculty members already working in the same organisation at a lower level and fulfilling the required qualifications compete with scholars applying from outside the institution. This mode commonly known as direct recruitment or promotion through open competition has been the most standard and had been the only avenue for upward mobility of the teachers in higher education institutions for a long time.

As per the present rules and regulations formulated by the UGC $(2010,2013)$, the eligibility criteria for direct recruitment for the position of Professor are Doctorate degree with at least ten years of academic experience, ten high quality research publications, and consolidated 400 points on academic performance index (API), formulated under the Performance Based Appraisal System. The weights assigned to different selection criteria are $20 \%$ for academic background, $40 \%$ for research, $20 \%$ for domain knowledge and teaching skills, and $20 \%$ for performance in interview, conducted specifically for this purpose. Similarly for the post of Associate Professor, one should have a PhD degree, good academic record (55\% marks) at Master's level, eight years of experience (at Assistant Professor level), five publications, and 300 points on API points. The weights for different selection criteria are same as those for the post of Professor. Applicants for the post of Assistant Professor should have good academic background (55\% marks) at Master's level, and pass in National Eligibility Test (NET) (or Doctorate Degree obtained before 2009). The selection criteria with weights include academic record (50\%), domain knowledge and teaching skills (30\%) and performance in interview $(20 \%)$.

Direct recruitment for the faculty positions used to be guided for a long period, by the same considerations, but for the academic performance index with differential weights for different selection criteria which was introduced recently. 
The main problem with the direct recruitment system is that the number of positions available for higher level positions is very limited, as such positions arise only when either the incumbent retires, or leaves for some reason or other, or in less frequent cases new positions are created with increase in student numbers, courses of study to be offered, and setting up of new institutions. Financial constraints also restrict the scope for creation of new positions and even filling the existing vacancies. Moreover, the reservation policies add to the problems, with the very limited number of vacant positions - existing or newly created, are subject to reservations for different social groups of population. Hence stagnation for long years has been a feature of the majority of the academic profession in the country, resulting in de-motivation and even deserting the academic profession altogether.

\section{Career Advancement Scheme (CAS)}

As an answer to some of these problems, career advancement scheme, also known during the earlier period as merit promotion scheme, was introduced in India first time in 1983, which allows promotion of the eligible faculty members to the next higher level, even if no vacant positions exist at the higher level. Its origin can be traced to the recommendation made first by the Education Commission (1966, p. 101): "An ad hoc temporary post in the higher grade should be created for lecturer or reader who has done outstanding work and who cannot be given his well-earned promotion because no suitable posts are vacant. He should then be absorbed against an appropriate permanent post as soon as it becomes available." As per the present practice, CAS promotees are not absorbed in regular posts, even if available. The Commission also further recommended that "before such promotions are made, the work of the persons concerned should be evaluated by a specially constituted expert committee and the approval of the UGC obtained". Promoting vertical mobility, the time-bound promotion scheme introduced in 1983 is regarded as an important solution to the problem of stagnation and to check exit rates from the given institution and from the academic profession as a whole. It is considered as a personal promotion, and once the faculty member retires or leaves, the vacancy would be treated at the lower level only from which promotion was made. Brought into address the issue of stagnation without promotional avenues, teacher turn over, low morale, the CAS assures promotion to next higher level, even when there is no clear position or vacancy at the next level. It promotes vertical mobility. With the merit promotion scheme assuring time bound promotion, teaching profession was expected to be no longer the last resort of talented graduates from the universities and colleges. 
Thus, teachers in higher education are also assured of promotions in their career, under the merit promotion scheme of the UGC, if they complete a minimum prescribed number of years of service at the given level and if performance is satisfactory. No single person was considered eligible for two subsequent promotions during the career of the faculty member. For a long period, there used to be a distinction maintained between CAS promotees and recruits through open competition. CAS promotees were also treated differently from others, say, for example for the headship of the departments where it was on rotation. Though the direct recruits continue to have an air of superiority and the CAS promotees are viewed with an inferior tag, for most official purposes no formal distinction is made between the two. Certainly the situation of the universities with too many faculty members promoted under CAS in relation to faculty members directly recruited is not considered as a healthy situation (see Figure 4).

The merit promotion scheme was criticised as it was regarded as essentially as a time-bound personal promotion scheme, with emphasis on seniority and with no concern for merit or performance of the faculty members. Mainly meant for rewarding merit, it culminated, despite some recommendations made by successive pay review committees, in time-bound promotion. The incentive for hard work got blurred. As Singh (2004, p. 209) observed, "It curbs initiative: even promotion to a professional post is based on a considerations which underemphasise academic achievement and overemphasise seniority."

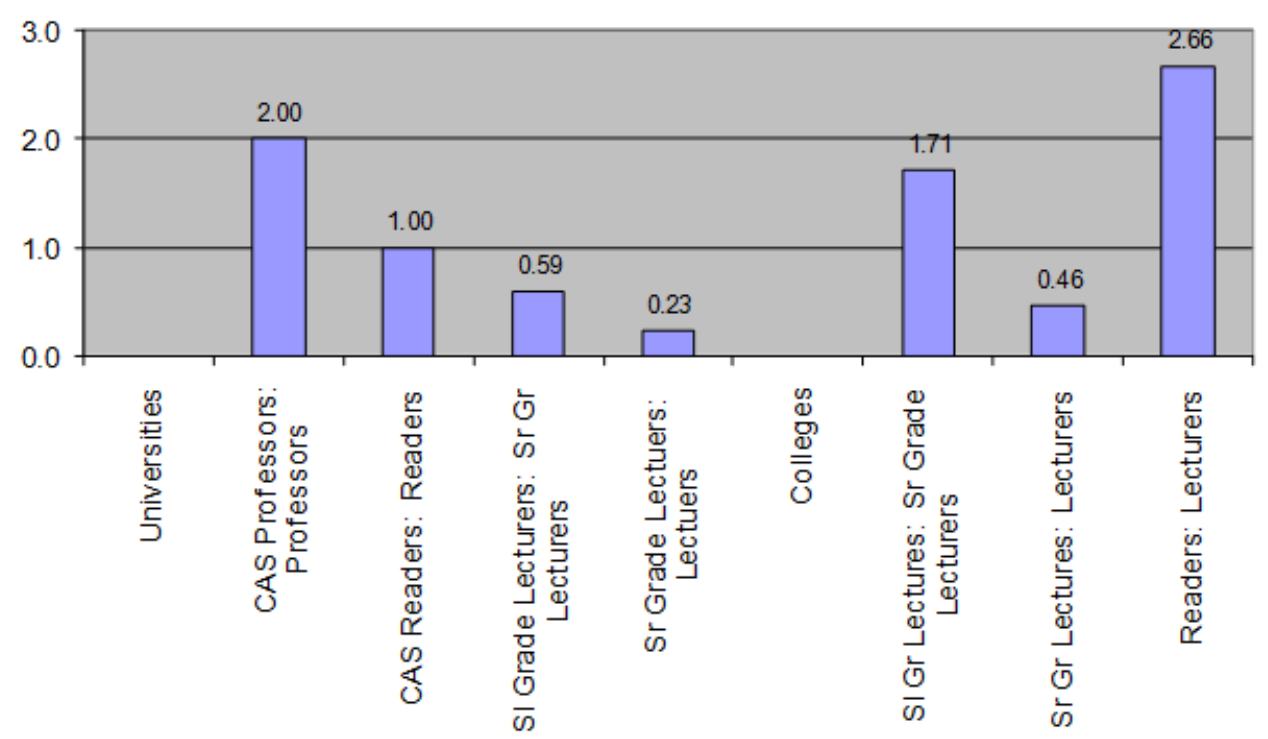

Figure 4. CAS Promotees (Ratio) in Universities and Colleges (Source: UGC, 2008) 
In practice, it became a right of every one, and the result was reckless promotion of all, not discriminating between deserving and undeserving, with no serious consideration for quality in research and teaching. No proper objective methods of evaluation of teacher performance were adopted. In effect, assessment of the performance was largely based on annual self appraisal of the teachers, and hence promotion became automatic subject to the number of years of service. Since this was subject to fulfillment of a bare minimum level of performance in teaching and research, it was widely held that the scheme would be counterproductive and would adversely affect the motivation of the teachers to excel in their work. For the same reason it was widely criticised not as merit promotion, but as 'mercy' promotion. Some attribute the decline in quality and standards in higher education and in the standards of academic profession to the merit promotion scheme. But the scheme has come to stay, as any action otherwise will incur the wrath of the teachers' unions. Only some marginal modifications have been periodically attempted over the years, until recently when major changes were made.

\section{Performance-linked Promotions and New Pay Scales}

Despite severe criticism, the Sixth Pay Revision Committee of the UGC (2008) recommended the continuation of the career advanced scheme, however, with a few additional qualifications, and along with it recommended revision in the pay scales, and increase in retirement age to 65 , with a provision for extension until the age of 70 for some. ${ }^{5}$ While modifying the career advancement scheme and revising the pay scales, the Sixth Pay Revision Committee has considered two important factors, viz., parity in pay scales of members of the academic profession with those of the civil servants, and secondly, parity in the promotional time-frame and the number of promotional grades between those of the academic staff and civil servants. Presently the long held sharp criticism raised about the utter lack of parity in career pay profiles of the two categories is no more valid, as there is a common and uniform grade pay increments across both services. In addition, the Sixth Pay Revision Committee formulated an elaborate set of parameters for the academic performance index for use in case of both promotion through direct recruitment and promotion through CAS.

First, the pay scales. The increases in pay scales of teachers, recommended by the Committee, mark very significant increases, though many states are yet to implement the revisions. There has been substantial revision in the salary scales of teachers across the board. Unlike the pre-Sixth Pay Commission situation, the teachers' salaries are no more, low as compared to other government services and corporate business. 
Jandhyala B. G. Tilak \& A. Matthew

Table 6. Pay scales of teachers (2008)

\begin{tabular}{clcc}
\hline Stage & & Pay Scale (Rs.) & Grade Pay (Rs.) \\
\hline 1 & Assistant Professor (1) & $15,000-39,100$ & 6000 \\
2 & Assistant Professor (2) & $15,000-39,100$ & 7000 \\
3 & Assistant Professor (3) & $15,000-39,100$ & 8000 \\
4 & Associate Professor & $37,400-67,000$ & 9000 \\
5 & Professor & $37,400-67,000$ & 10000 \\
6 & Professor (HAG) & $37,400-67,000$ & 12000 \\
6 & Professor (HAG) & $67,000-79,000$ & nil \\
\hline
\end{tabular}

Note: Current (January 2015) exchange rate: INR60 = USD1 (approximate)

In fact, the starting gross monthly salary of an Assistant Professor today is Rs. 42,400, Associate Professor, Rs. 85,800 and Professor Rs. 97,400 (Jayaram, 2012). The revision in the salary scales with additional allowances meant a whopping hike of $70 \%-90 \%$ pay hike over the then existing levels. Though from the point of view of international comparisons, the salary levels seem to be low, they are not that bad in comparison with salary structure of others in the public sector in the country, and the relative purchasing power of the money. They are somewhat globally competitive salaries. They are also uniform across the whole country.

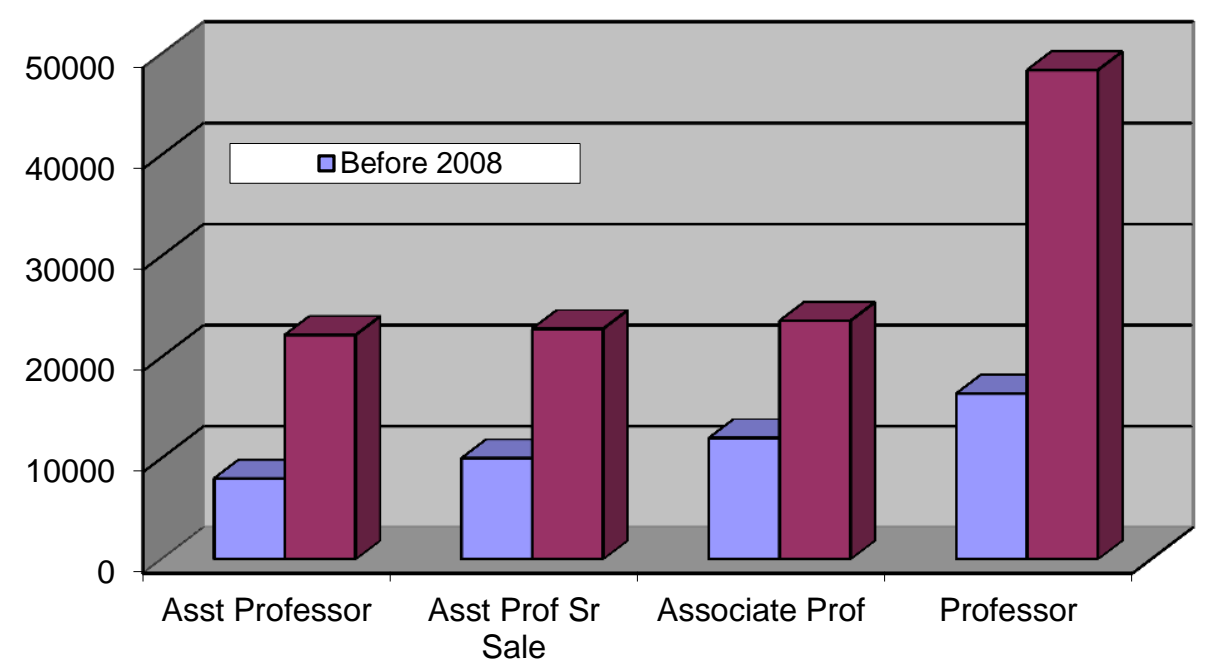

Figure 5. Revision in teachers' salaries in universities and colleges (Rs. at the beginning level: Basic Pay + Grade Pay) 
While the new pay scales are widely welcomed, it is also argued that the pay scales are common for stages 1,2 and 3 and stages 4,5 and 6 , whereas differential starting scales of pay could have been judicious. There are differences only in Grade Pay. There is not much difference between stages 4 and 5. There is no significant financial reward when promoted to the next stage, say between Stages 1, 2 and 3; or between stages 4 and 5, and between 5 and $6 .{ }^{6}$

The pay revision committee has also recommended better/faster upward mobility of teachers.

The Career Advancement Scheme formulated by the Sixth Pay Revision Committee, came into force in 2010 and revised in $2013,{ }^{7}$ is based on certain clear cut criteria viz., years of experience, score on Academic Performance Index (popularly known as API Score), and assessment by the Selection/Screening/Expert Committee. The API scores take into account:

1. Teaching (including innovations in teaching, syllabus improvement, examinations, evaluation, etc. [minimum score ranging from minimum 25 to 125 points]).

2. Co-curricular, Extension, profession-related activities, including academic administration, relations with corporate sector, seminars, etc.[the range of the score being minimum 15 and maximum 50 points]

3. Research, including papers/chapters, books, projects, seminar/conference papers and research guidance.

Under each of these three areas, a large number of indictors are identified and their respective score points are specified. By doing so, it aimed at reducing scope for biases and favouritism in the process of promotion (and also recruitment), and at the same time encourage, motivate and reward teachers in their academic pursuits (Das \& Chattopadhyay, 2014, p. 68).

Specific minimum eligibility conditions for promotion at each level are different and they are given in Table 7. Every category-teaching, extension and research-consists of several items in good derails and for each points are assigned. ${ }^{8}$ The API score system including all the criteria, minimum eligibility conditions, relative weights and points for various performance indicators are applicable in case of both direct recruitment and promotion and under career advancement scheme.

The attempt in making the elaborate and systematic API under the Performance Based Assessment System was to provide for a 360-degree assessment of contributions of the faculty members to diverse aspects of academic profession. 
Though the format and all the conditions are given in elaborate detail, it was also claimed to be leaving enough space for universities to modify the format within the framework to make a comprehensive assessment.

Table 7. Minimum eligibility conditions for promotion under career advancement scheme revised (2013)

\begin{tabular}{ll}
\hline Conditions & Minimum eligibility \\
\hline Promotion from Stage 1 to Stage 2 & \\
\hline Experience at Stage 1 & \\
- Experience for those with PhD degree & 4 years \\
- Experience for those with MPhil & 5 years \\
API score $\quad$ Experience for those with no MPhil/PhD & 6 years \\
- Teaching & \\
- Extension & 75 points per year \\
- Teaching \& Extension $\quad$ Research & 15 points per year \\
- for College teachers & 100 points per year \\
& 10 points per year/40 points for the \\
Assessment of Screening Committee & assessment period \\
\hline
\end{tabular}

Promotion from Stage 2 to Stage 3

Experience at Stage 2

- $\quad$ Experience for those with $\mathrm{PhD}$ degree 5 years

API score

- Teaching

75 points per year

- Extension

15 points per year

- Teaching \& Extension

100 points per year

- Research

20 points per year/100 points for the assessment period

- for College teachers

10 points per year/50 points for the assessment period

Assessment of Screening Committee

Positive/ Verification of the API scores

Promotion from Stage 3 to Stage 4

\begin{tabular}{ll}
\hline Experience at Stage 3 & 3 years \\
API score & \\
- $\quad$ Teaching & 75 points per year \\
- $\quad$ Extension & 15 points per year \\
\hline
\end{tabular}

(continue to next page) 
Table 7. Continued

- Teaching \& Extension

- Research

- $\quad$ for College teachers

Assessment of Selection Committee

Relative Weights

- Research

- Teaching

- Interview

For college teachers

- Research

- Teaching

- Interview

Promotion from Stage 4 to Stage 5

\section{Experience at Stage 4 \\ API score \\ - $\quad$ Teaching \\ - Extension \\ - Teaching \& Extension \\ - Research \\ - $\quad$ for College teachers}

Assessment of Selection Committee

Relative Weights
- Research
$50 \%$
- Teaching
$30 \%$
- Interview
$20 \%$
$\%$

for college teachers

- Research

$20 \%$

- Teaching

$60 \%$

- Interview

$20 \%$
100 points per year

30 points per year/90 points for the assessment period

5 points per year/20 points for the assessment period

Positive

$30 \%$

$50 \%$

$20 \%$

$20 \%$

$60 \%$

$20 \%$

3 years

75 points per year

15 points per year

100 points per year

15 points per year/45 points for the assessment period

5 points per year/20 points for the assessment period

Positive 
Table 7. Continued

\begin{tabular}{ll}
\hline Promotion from Stage 5 to Stage 6 & \\
\hline (Limit: $10 \%$ of Professors in the Organisation) & \\
Experience at Stage 5 & 10 years \\
API score & 75 points per year \\
- Teaching $\quad$ Extension & 15 points per year \\
- Teaching \& Extension & 100 points per year \\
- Research & 50 points per year $/ 500$ points for the \\
Assessment by Expert Committee & assessment period \\
Relative Weights & Positive \\
- Research & $50 \%$ \\
- Performance Evaluation & $50 \%$ \\
\hline
\end{tabular}

Source: UGC (2010; 2013)

The API is regarded as India's first major attempt at ensuring that teacher recruitment and promotions are directly linked to their academic performance. The process of recruitment and selection would be transparent, objective and credible, ensuring a sound and systematic methodology of assessment of the credentials of the teachers in higher education. Introduced along with the steep increases in pay scales of teachers, the performance assessment system is aimed at increasing the accountability of the teachers to improve the standard of higher education institutions in the country.

Though some noted that this marks a very significant improvement over the prevailing system, introducing a high degree of objectivity in assessment of the teachers' performance and in widening promotional opportunities, it is not spared from serious criticism by the academic community. While the pay increases were widely welcomed, the application of academic performance index was subject to severe criticism.

The problems with CAS system are too many and too complicated. The API score system is regarded as a very cumbersome process, flawed and that there was room for manipulation and the documentation process tedious, cumbersome and time-consuming.

Though some variations are provided for, broadly uniform criteria were applied for all institutions without taking into account the sharp variations in the facilities in conducive environment for teachers' performance. Some argue that the API score system gives undue high weights to research and less to teaching and 
further less to extension activities and social functions. The API score system also discourages joint work and department-level team work, and encourages individual concerns, as the same points are divided between the team members in case of joint and collaborative activities. Yet there is obsession with API score and teachers get occupied with manipulating and accumulating their API scores by attending more and more seminars, even if they are not much relevant, and publishing more papers in poor quality and non-refereed journals, and become busy filling up forms. In general, teachers may choose soft options of the API like attending conferences, workshops, symposiums, training programmes and publication of articles in journals of low or zero credibility ${ }^{9}$ and even books with cheap publishers on payment, etc., and avoid tougher ones, like undertaking major research projects and publication of research papers in standard journals. There is no proper mechanism to monitor the quality of research or assess the commitment of the teachers. In short, as Kumar (2013) observed, the API has been "initiated to quantitatively measure the performance of academics. It has set into motion a process of weeding out the committed academics in favour of mediocrity and paper chase." It was also criticised on two other grounds. First, the strict and inflexible requirements as per the API score system, are responsible for slowing down recruitment, and adding to large scale teaching vacancies in higher education institutions. Second, the API system with all its rigidly specified detailed conditions is said to be going against the concept of university autonomy on the one hand, and the autonomy of the states on the other. Thirdly, the standardised system of assessment does not differentiate between different universities and colleges, though distinction is made between universities and colleges and between social sciences and humanities on the one hand and natural and other sciences on the other; discriminate between high and low quality contributions of the teachers to the profession.

Many of the indicators are subjective and several are regarded as unfair and also not relevant for teachers in many higher education institutions in India, say for teachers in colleges, who, like in many other countries, are not "creative intellectuals," but are "consuming intellectuals" essentially involved in transmitting knowledge, and not much in research publication (Altbach, 1977); and colleges are also severely short of basic infrastructure, research support, etc. Some view that the assignment of points and weights for each activity and the whole quantification process is highly simplistic, mechanical, and demeaning, ignoring the human and intellectual dimensions of teaching profession. It assumes that teacher performance or teacher efficiency can be reduced to a score, which is seriously resented by many. As Bhattacharya (2013) wondered, whether the API system is meant to "grade or degrade" teachers. 
The levels of faculty positions for promotion are many - as many as six! It takes a minimum of 16 years for one who joins as an Assistant Professor to get promoted as a Professor (stage 5).

Despite the fact that it is a significant improvement over the earlier models of career advancement, in view of large scale resentment continuing criticism from the teaching community, the UGC had withdrawn the API system as whole in January 2013, but quickly retraced its steps and restored it in June 2013 with a few important modifications in the API system at the university level-in the procedures and in the assignment of score points for each of the performance indicator and relative weights to them. ${ }^{10}$ The revisions include changes in the score points for some items, capping score points on some items and changes in relative weights for some. More importantly, the revisions provided for flexibly for the universities to adopt, adapt and interpret the API in their own way. Universities are required to rate teachers, but can set the parameters themselves, and to encourage transparency, give teachers a point-based score, based on a university-developed index. The universities are also given flexibility to evolve their own mechanisms to assess teacher performance, based on their own performance based appraisal system and the API scores. Initially API was to provide an objective system of assessment of a teacher's accountability and performance, but after the 2013 it was made just a screening mechanism and not meant for expert assessment. If candidates fulfill stipulated cut-off points, they are called for interviews, and the screening/selection committees are entrusted with final responsibility of making a comprehensive assessment of the applicants and make the final decision. As the API score cannot be taken as the final decisive one, the API remains as a bureaucratic/clerical exercise of least significance. Yet API stays and it matters.

Some of the discontentment among the teaching community was not favourably viewed by many, as it was felt that teachers have been opposing since the API scores are based on performance of the faculty based on research publications, teaching, innovations, and other activities, that require teachers to actually work hard consistently for years for promotion, in contrast to 'automatic promotion' after a given number of years, which was the de facto practice earlier in many universities.

But some criticism seems to be valid. The whole system continues to maintain that the teacher performance could be reduced to a single score; though standardization cannot be avoided, and any composite index by its very nature turns out be a single number, the scoring pattern does not differentiate between poor quality and high quality research, instant/short term research and long term engagement in fundamental and path-breaking research or creative writing, 
between mediocre teaching and inspiring teaching, etc. The system continues to altogether ignore student evaluation or student feedback on teacher performance.

The use of API and CAS as a whole in practice is not so efficient as it appears. While the essence of the point system of the API was retained by all universities in practice, by maintaining the mandated cut-off points, the spirit was compromised in terms of quality. Points for publications and activities are manipulated by universities to suit their specific situations, thereby diluting the API system. But in the processes of making it flexible, it is found to be allowing "infusion of subjectivity and discretion" as well (Das \& Chattopadhyay, 2014, p. 71). Theoretically, promotion under CAS is not automatic but it is actually the case in practice. Teachers view it almost as a right, and as there is no competition for such promotions, no need to excel or at least perform well. University administrators might also feel as if they have no choice but to follow the CAS system and promote the faculty to higher levels. CAS leaves no scope for competition. In the CAS approach there is not enough consideration for quality research, commitment, seriousness and devotion in teaching. Members rejected under competitive promotion scheme can get promoted under CAS. Even when positions are available under direct open recruitment in the same organisation or outside, many tend to opt for less rigorous option of promotion under CAS. Some critical parts of the process are highly subjective highly subjective leading to nepotism and favouritism. No provision exists in the CAS system for any kind of student evaluation of teacher performance. With large scale promotions, it is feared that the structure of teaching staff in the universities is changing from a typical pyramidal structure to a cylindrical one and then to an inverted pyramid, with a larger number of professors and associate professors and a smaller number of lecturers and assistant professors.

Despite many shortcomings, it may have to be acknowledged that the elaborate assessment system used for promotion in universities and colleges in India, tries to straddle the difficult balance between objective and needed subjective assessment of performance of academic faculty and also between ensuring the autonomy of varsities and improving faculty accountability. It is not a perfect system, but it cannot be perfect. To conclude, it is widely felt that to ensure a place among the top institutes in the world, an efficient evaluation system should be introduced and the PBAS and the API systems should be revised taking into consideration local specific conditions, national concerns and international environment. UGC has recognised the need to relook at the API indictors and sought in its latest communication in April 2015 to the universities, their views in this regard. It is hoped that after wider consultations, a clearly formulated scientific system of performance evaluation is firmly put in place, which does not require frequent modifications or revisions, and certainly not its withdrawal and 
reintroduction, and which is accepted not only by all within the country, but also internationally.

\section{ACKNOWLEDGEMENTS}

This paper has been presented in the UNESCO Bangkok ERI-Net Research Seminar on 'Academic Promotion of Teaching Personnel in Higher Education,' Zhejiang University, Hangzhou, People's Republic of China (26 to 28 November 2014). An edited version of the article is to appear in Academic Promotion of Teaching Personnel in Higher Education: Case Studies from Asia and the Pacific. Paris, UNESCO \& UNESCO Bangkok.

\section{NOTES}

1. Higher education institutions in India essentially consist of universities and colleges. Every college is necessarily affiliated to a university, or is a constituent college of a university. Most colleges offer under-graduate (Bachelors' level) programmes, and some post-graduate (Masters' level) programmes. Though colleges are an important part of the system, one finds big difference between universities and colleges with respect to a variety of dimensions.

2. The salary scales adopted at that time were: Rs.300 for lecturers, Rs.600 for readers and Rs. 900 for professors.

3. Universities are free to upgrade the minimum eligibility qualifications. For example, quite a few universities insist on good academic record not only at Master's level studies, but also at Bachelor's Degree level; some redefine 'good' academic record as. First class, not just 55\% marks. Depending upon the number of applications received for each post, the screening committees generally set higher minimum qualifications.

4. As per the Constitutional mandate, $49.5 \%$ of the posts are reserved for socially backward sections of the society: $15 \%$ for Scheduled Castes, $7.5 \%$ for Scheduled Tribes and 27\% for 'other' backward classes. Besides this 'vertical' reservation, there is 'horizontal' reservation to the extent of $3 \%$ (across categories) for people with disability and $1 \%$ each for auditory, visual and orthopedic disabilities. All vacant posts are necessarily advertised and number of posts reserved for each category is also to be mentioned. If candidates from the specified category are not available, the vacant positions need to be re-advertised; they cannot be filled with candidates from non-reserved categories.

5. See UGC (2010) for full details. 
6. Promotion from stage 5 to stage 6 is also conditioned by the total number of positions at the level of stage 5 in the university, and only $10 \%$ of such positions can be promoted to stage 6 , subject to a very high level of academic performance, evaluated by an expert committee.

7. In response to widespread criticism from the teaching community, the UGC had withdrawn the API system as whole in January 2013, but quickly retraced its steps and restored it in June 2013 with a few important modifications.

8. See UGC $(2010,2013)$ for points in detail for each component - like, for example, points for publication of papers in journals, points for publication of books, points for attending seminars, points for conducting seminars, teaching hours, examination related work, etc.

9. It also seems to have contributed to proliferation of journals of all types, some of which, particularly online ones, promise to publish articles in a couple of weeks after submission, provided publication fees/charges are paid.

10. For example, so as to prevent teachers to increase their API scores by attending too many seminars/workshops etc., the UGC amended the regulations in such a manner that maximum $15 \%$ of API would be allocated for participation in conferences, seminars and training courses.

\section{REFERENCES}

Altbach, P. G. (1977). In search of Saraswati: The ambivalence of the Indian academic. Higher Education 6(2): 255-275. http://dx.doi.org/10.1007/BF00141881

Altbach, P. G. (Ed.) (2002). The decline of the guru. Chestnut Hill, MA: Boston College.

Basu, K. (2005). Teacher truancy in India: The role of culture, norms and economic incentive. Indian Economic Journal, 53(2): 3-12.

Bhattacharya, R. (2013). UGC's Academic Performance Index: Will it grade or degrade teachers? MeriNews (31 May). Retrieved 15 May 2015 from http://www.merinews.com/article/ugcs-academic-performance-index-will-itgrade-or-degrade-teachers/15883514.shtml

Chadh, G. K., Bhushan, S., \& Murlidhar, V. (2008). Teachers in Universities and Colleges: Current status regarding availability and service conditions. In Higher Education in India: Issues Related to Expansion, Inclusiveness, Quality and Finance (pp. 203-213). New Delhi: University Grants Commission.

Das, D. N., \& Chattopadhyay, S. (2014). Academic performance indicators: Straitjacketing higher education. Economic and Political Weekly, 49(50), 68-71.

Education Commission. (1966). Education and national development: Report of the Education Commission 1964-1966. New Delhi: National Council of Educational Research and Training [reprint 1971].

Government of India. (1976). Report of the Sen Committee on the governance of Universities and Colleges. New Delhi: Ministry of Education. 
Government of India. (1986a). National Policy on Education 1986. New Delhi: Ministry of Education.

Government of India. (1986b). National Policy on Education 1986: The Programme of Action. New Delhi: Ministry of Education.

Jayaram, N. (2002). The fall of the Guru: The decline of the academic profession in India. In P. G. Altbach (Ed.), The decline of the Guru (pp. 207-240). Chestnut Hill, MA: Boston College.

Jayaram, N. (2012). Academic salaries and career advancement: Tuning the professoriate for a knowledge economy. In P. G. Altbach, L. Reisberg, M. Yudkevich, G. Androushchak, \& I. F. Pacheco (Eds.), Paying tee professoriate: A global comparison of compensation and contracts (pp. 155-165). New York: Routledge.

Kumar, A. (2013). Delhi University and the crisis in India's Higher Education. Economic and Political Weekly 48(24) (June 15). Retrieved 10 April 2015 from http://www.epw.in/print/debating-du/delhi-university-and-crisis-india\%E2\% 80\%99s-higher-education.html

Kumar, T. R., \& Raina, B. (1997). Rastogi committee on pay structure: Disincentives reinforced. Economic and Political Weekly, 32(31) (2 August), 1985-1990.

Kumar, T. R., \& Sharma, V. S. (2008). Pay structure in higher education: Some issues. Economic and Political Weekly 43(16) (19 April), 9-22.

Ministry of Education (MOE). (1950). The report of the University Education Commission (December 1848-August 1949) (Vol. 1). Delhi: Government of India.

Ministry of Human Resource Development. (various years). All-India Survey of Higher Education. New Delhi: Government of India. Retrieved 14 May 2015 from http://mhrd.gov.in/statist?field_statistics_category_tid=32

Ministry of Human Resource Development. (various years). Statistics of Higher and Technical Education. New Delhi: Government of India. Retrieved 10 May 2015 from http://mhrd.gov.in/statist?field_statistics_category_tid=32

Ministry of Human Resource Development. (various years). Education in India. New Delhi: Government of India.

National Commission on Teachers (NCT). (1985). Report of the National Commission on Teaches in Higher Education. New Delhi: National Institute of Educational Planning and Administration.

Qamar, F. (2008). Status of quality in higher education varying perceptions. In Higher Education in India: Issues related to expansion, inclusiveness, quality and finance (pp. 199-202). New Delhi: Univeristy Grunts Commission.

Singh, A. (2004). Fifty years of Higher Education in India. New Delhi: Sage.

Tilak, J. B. G. (2007). Empowerment of higher education and academic profession in India: Problems and challenges. In Constructing university visions and the mission of academic profession higher education in Asian countries: A comparative perspective (pp. 123-137). Hiroshima: Hiroshima University, Regional Institute for Higher Education (COE Publication Series 23).

University Grants Commission (UGC). (1986). Report of the committee on revision of pay scales of teachers in universities and colleges (also known as Mehrotra Committee). New Delhi: Author. 
UGC. (1997). Report of the committee to review the pay scales of university and college teachers (also known as Rastogi Committee). New Delhi: Author.

UGC. (1998). Notification on revision of pay scales, minimum qualification for appoint of teachers in universities, colleges and other measures for the maintenance of standards, 1998. New Delhi: Author.

UGC. (2008). Report of the committee to review the pay scales and service conditions of university and college teachers, 2008. New Delhi. Retrieved 20 May 2015 from http://pib.nic.in/archieve/others/2008/oct/b2008100601.pdf

UGC. (2010). Minimum qualifications for appointment of teachers and other academic staff in universities and colleges and other measures for the maintenance of standards in higher education. New Delhi: University Grants Commission (13 June), Gazette of India, 18 September 2010. Retrieved 21 May 2015 from http://www.ugc.ac.in/policy/englishgazette.pdf

UGC. (2013). Minimum qualifications for appointment of teachers and other academic staff in universities and colleges and other measures for the maintenance of standards in higher education (2nd Amendment) 2013. New Delhi, Gazette of India, 13 June. Retrieved 20 May 2015 from http://www.bhu.ac.in/rac/ regulation/8377302_English.pdf

UGC. (various years) Annual report. New Delhi: Author. 